\title{
Consuming Fat Supplemented Diet with Different Vegetable Oils Impacts the Serum Lipid Profiles and Body Weights of Male Rats
}

\author{
Mahitab H. El Bishbishy, PhD \\ Department of Pharmacognosy, Faculty of Pharmacy, \\ MSA University, Giza, Egypt \\ Nora M. Aborehab, PhD \\ Department of Biochemistry, Faculty of Pharmacy, \\ MSA University, Giza, Egypt
}

Doi: 10.19044/esj.2018.v14n30p275 URL:http://dx.doi.org/10.19044/esj.2018.v14n30p275

\begin{abstract}
This research was conducted in order to evaluate the influence of consuming diet supplemented with different types of fixed oils (Olive oil, Soybean oil and Coconut oil) on the lipid profiles and body weights of healthy albino rats and linking these effects to their chemical compositions thus reaching out to recommendation about the healthiest type of fats among the studied oils to be used in healthy nutrition programs. The lipid contents of the fixed oils were determined by Gas Chromatography (GC) method, the vitamin contents were determined by High Performance Liquid Chromatography (HPLC) and the proximate analyses of the oils were also evaluated by different assays. Twenty-four healthy male albino rats were divided into four groups as follows: Olive oil supplemented diet, Soybean oil supplemented diet, Coconut oil supplemented diet and oil-free supplemented diet control group. The dieting continued for 28 days, at the end of which, the serum levels of total cholesterol, Low Density Lipoproteins (LDL), High Density Lipoproteins (HDL), Triglycerides (TG) and Free Fatty Acid (FFA) were measured spectrophotometrically and the rats body weights were monitored on daily basis. The results showed that olive oil, the richest studied oil in unsaturated fatty acids $(84.16 \%)$, had favorable effect on the rats' lipid profiles, serum free fatty acid levels and rats body weights. In conclusion, olive oil supplemented diets are considered healthy diets and beneficial to decrease the risk of cardiovascular diseases.
\end{abstract}

Keywords: Olive oil; Soybean oil; Coconut oil; Fatty acids; Cholesterol 


\section{Introduction}

Cardiovascular diseases (CVD) are the number one cause of death worldwide, responsible for the deaths of around eighteen million people every year, representing thirty-one percent of all global deaths. (Mendis et al. 2011) (World Health Organization 2017). Development of atherogenesis and coronary heart diseases have many risk factors including hyperlipidemia (Prasad et al. 2016). The American Heart Association Scientific Advisory reported that diets enriched with Monounsaturated Fatty Acid (MUFA) tend to raise the levels of High Density Lipoproteins (HDL) and lower that of triacylglycerol (Kris-Etherton 1999; Lichtenstein et al. 2006). Also, several epidemiological and clinical studies indicated that omega-3 Polyunsaturated Fatty Acid (PUFA) could prevent coronary heart diseases through different mechanism as antiarrhythmic, hypolipidemic and antithrombotic roles (Esrey et al. 1996; Howard et al. 2006; Rabrenovic 2011). A further evidence is that Mediterranean regions show significantly lower incidence of CVD, this could be attributed to their dietary habits (Martínez-González and Sánchez-Villegas 2004). Long-term intake of olive oil, a fundamental component of the Mediterranean diet, that contains high concentrations of MUFA, was proved to reduce the risk of developing hypertension (Alonso and Martínez-González 2004; Estruch et al. 2006). Accordingly, approaches for the prevention and treatment of coronary heart diseases should include population dietary modification (Rajaram et al. 2001; Hu and Willett 2002).

Balanced healthy diet is defined as having a variety of food that provides important nutrients for health maintenance and prevention of a number of serious conditions including mainly CVD. A healthy diet should contain adequate proportion of carbohydrates, fats, and proteins "macronutrients" along with the recommended daily allowances of vitamins, minerals "micronutrients". The recommended daily fat intake for healthy adults should be within 15 to $30 \%$ of total caloric intake (World Health Organization 2008).

Unfortunately, many people were scared away from using vegetable oils during the low-fat craze of the last decades, as they believed in a myth that these oils are unhealthy food and hyperlipidemia is caused by increased fats proportion in diet, but actually hyperlipidemia was found then to be mainly attributed to the type of fats supplied rather than the amount (German and Dillard 2004). Scientific evidence has provided reliable and significant results approving the association between diets high in SFAand increased serum cholesterol level which ultimately leads to building up of fatty plaque on the walls of blood vessels, atherosclerosis and consequently heart attacks and strokes (Siri-Tarino et al. 2010). Other studies proved that atherosclerosis and CVD risks increase with the elevation of serum cholesterol as well as with the the type of fats. Also, it is well known that the dietary SFA and cholesterol 
raise total blood cholesterol and low density lipoprotein (LDL) cholesterol levels, while PUFA lowers total blood cholesterol and LDL cholesterol levels (Pietinen et al. 1997; Xu et al. 2006). The (World Health Organization 2008) confirmed that replacing SFA with PUFA decreases LDL cholesterol concentration and the total/HDL cholesterol ratio. Thus, it is recommended to reduce the SFA intake to less than $10 \%$ of calories (Zimmerman and Snow 2012).

In keeping with this evidence, we decided to evaluate the impact of three vegetable oils namely, olive oil, soybean oil and coconut oil on the lipid profiles of healthy albino rats aiming to identify the healthiest type among the selected oils. The intention for using these oils in particular is the variability of the degree of saturation of their fatty acid content. This variability allows further confirmation to relate the degree of fatty acid saturation to the effect on lipid profile and consequently the incidence of CVD.

\section{Material and Methods}

\section{Material for phytochemical investigations}

Olive oil (Olea europaea L., Family Oleaceae), soybean oil (Glycine $\max$ L. Merr., Family Fabaceae) and coconut oil (Cocos nucifera L., Family Arecaceae) were purchased from local Egyptian market. All chemical reagents and solvents were analytical grade (E-Merck, Darmstadt, Germany). Authentic vitamins (A, B3, B6, B12, C and E) were kindly supplied by the Agricultural Research Center, Food Technology Research Institute, Giza, Egypt. Authentic Fatty acids and Hydrocarbons standards were kindly supplied by National Research Center, Giza, Egypt.

\section{Determination of vitamins by HPLC}

The vitamin content of the three oils was assayed using an Agilent 1260 infinity HPLC Series (Agilent, USA), equipped with Quaternary Pump, a Kinetex XB-C18 Column $100 \mathrm{~mm}$ x 4.6mm (Phenomenex, USA), operated at $35^{\circ} \mathrm{C}$. The separation is achieved using a binary linear elution gradient with (A) $25 \mathrm{mM} \mathrm{NaH}_{2} \mathrm{PO}_{4} \mathrm{PH}=2.5$ (B), Methanol (v/v). The injected volume was $20 \mu$ l. Detection: VWD detector set at $254 \mathrm{~nm}$ for ascorbic acid, $280 \mathrm{~nm}$ for vitamins $\mathrm{A}$ and $\mathrm{E}$ and $220 \mathrm{~nm}$ for vitamins B. Quantitation was achieved at by an internal standard method (Evangelisti et al. 1997). Vitamin C content was determined according to (Romeu-Nadal et al. 2006), fat-soluble vitamins (A and E) were determined according to (Beyer and Jesnsen 1989) method while vitamins B was determined as described by (Batifoulier et al. 2005)

\section{Determination of mineral content}

The mineral content of the three studied oils was determined according to A.O.A.C guidelines (AOAC 1995). Oil samples were separately wet 
digested in an Advanced Microwave Digestion System ETHOS 1 with concentrated sulfuric acid and digestion catalysts (a mixture of copper sulfate and anhydrous sodium sulfate, 1:10), then the digested solutions were measured using an Atomic Absorption Spectrometer (Inductively Coupled Plasma ICP-AES Spectrometer, iCAP 6000 series, Thermo Scientific).

\section{Determination of amino acids content}

The amino acids content of the three studied oils was analyzed on an Automatic Amino Acid Analyzer AAA400 INGOS Ltd. Czech Republic, adopting the method of (Cosmos and Simon-Sarkadi 2002).

\section{Determination of lipid content by GC For unsaponifiable matters}

Unsaponifable matters were separated using HP- Hewlett Packard GCsystem, series 6890 equipped with Flame Ionization Detector (FID). A capillary column (HP-5 5\% phenyl methyl siloxane, 30m x $320 \mu \mathrm{m}$, film thickness $0.25 \mu \mathrm{m}$ ) was used in the separation. The injector port temperature was set $240^{\circ} \mathrm{C}$ (split mode) and the detector cell at $280^{\circ} \mathrm{C}$. The flow rate of the carrier gas, $\mathrm{N} 2$, was $20 \mathrm{ml} / \mathrm{min}$, for $\mathrm{H} 220 \mathrm{ml} / \mathrm{min}$ and for air $200 \mathrm{ml} / \mathrm{min}$. The column temperature was $80^{\circ} \mathrm{C}$ for $1 \mathrm{~min}$ and then increased to $280^{\circ} \mathrm{C}$ by the rate of $8^{\circ} \mathrm{C} / \mathrm{min}$, with maximum column temperature $325^{\circ} \mathrm{C}$ then isothermally for a total run time of 20 minutes.

\section{For fatty acid methyl esters}

Fatty acid methyl esters were separated by the same GLC apparatus as unsaponifable matters. A capillary column (HP-5 5\% phenyl methyl siloxane, $30 \mathrm{~m} \times 320 \mu \mathrm{m}$, film thickness $0.25 \mu \mathrm{m}$ ) was used in the separation. The injector port temperature was set $250^{\circ} \mathrm{C}$ (splitless mode) and the detector cell at $280{ }^{\circ} \mathrm{C}$. The flow rate of the carrier gas, Hydrogen flow $30 \mathrm{ml} / \mathrm{min}$, air flow $300 \mathrm{ml} / \mathrm{min}$ and $\mathrm{N} 2$ was $10 \mathrm{ml} / \mathrm{min}$. The column temperature was $70^{\circ} \mathrm{C}$ for 1 min and then increased to $220^{\circ} \mathrm{C}$ by the rate of $4^{\circ} \mathrm{C} / \mathrm{min}$, then isothermally for a total run time of 20 minutes.

\section{Experimental animals}

Twenty-four Sprague-Dawley male albino rats, weighting $200 \pm 20 \mathrm{gm}$ obtained from the animal house of MSA University were used for this study. Prior to the initiation of the studies, the animals were randomized and assigned to treatment groups. Four rats were housed per cage $($ size $26 \times 41 \mathrm{~cm}$ ) and placed in the experimental room for acclimatization a week before the experiment. The animals were fed with standard laboratory diet and with tap water ad libitum, and kept under hygienic conditions and in an air-conditioned animal room at $23 \pm 1{ }^{\circ} \mathrm{C}$ with a $12 \mathrm{~h}$ light/dark cycle. 


\section{Experimental design}

Rats were randomly allocated into four groups of six animals each. Fed according to Table 1.

Group 1: Normal control group and had no oil in the feed

Group 2 (Soybean oil): rats received the soybean oil supplemented diet 30\% for 28 days

Group 3 (Coconut oil): rats received the coconut oil supplemented diet $30 \%$ for 28 days

Group 4 (Olive oil): rats received the olive oil supplemented diet $30 \%$ for 28 days

Table 1: Dietary composition of olive oil, soybean oil and coconut oil supplemented feed

\begin{tabular}{|l|c|c|c|c|}
\hline $\begin{array}{l}\text { Diet } \\
\text { composition }\end{array}$ & $\begin{array}{c}\text { Control } \\
\text { group }\end{array}$ & Olive oil group & $\begin{array}{c}\text { Soybean oil } \\
\text { group }\end{array}$ & $\begin{array}{c}\text { Coconut } \\
\text { oil group }\end{array}$ \\
\hline Corn & 69 & 39 & 39 & 39 \\
\hline Fish meal & 5 & 5 & 5 & 5 \\
\hline Groundnut & 10 & 10 & 10 & 10 \\
\hline Bone meal & 5 & 5 & 5 & 5 \\
\hline Palm oil & 5 & 5 & 5 & 5 \\
\hline Soya bean oil & -- & -- & 30 & -- \\
\hline Coconut oil & -- & -- & -- & 30 \\
\hline Olive oil & -- & 30 & -- & -- \\
\hline Vitamin & 1 & 1 & 1 & 1 \\
\hline Corn starch & 5 & 5 & 5 & 5 \\
\hline Total & 100 & 100 & 100 & 100 \\
\hline
\end{tabular}

\section{Blood samples and biochemical analysis}

\section{Preparation of blood samples}

At the end of the study, rats were fasted overnight, anesthetized with thiopental sodium $(50 \mathrm{mg} / \mathrm{kg}$ ) (Vogler et al. 2006) and blood samples were collected ( $5 \mathrm{ml}$ per rat). Blood samples were centrifuged at $3000 \mathrm{rpm}$ for 15 min after 30 minutes of collection and stored at $-80^{\circ} \mathrm{C}$ until analyzed. Serum Total cholesterol (TC), LDL, HDL, TG and FFA were determined using colorimetric assay kits.

\section{Biochemical analysis}

Analysis of serum was carried out for measuring TC, LDL and HDL levels using colorimetric assay kit (Biochain, USA), TG using enzymatic assay kit (XpressBio life science products, USA) and FFA using Abnova colorimetric assay kit

\section{Statistical analyses}

All data were expressed as mean \pm SD and analyzed using Prism program version 6 . For all parameters, comparisons among groups were 
carried out using one-way analysis of variance (ANOVA) followed by Bonferroni's multiple comparisons test. All $\mathrm{P}$ values reported are two-tailed and $\mathrm{P}<0.05$ was considered significance.

\section{Ethics Statement}

Animal care and handling was performed in conformance with approved protocols of MSA University and Egyptian Community guidelines for animal care.

\section{Results}

\section{Nutritional profiles of the oils}

The fat soluble vitamins (A and E) clearly predominates the water soluble ones as (vitamin C and B). Soybean oil was found to have the highest concentration of vitamin A amongst the studied oils, while coconut oil had the highest concentration of vitamin E. The studied oils exhibited relatively high amounts of sodium, moderate amounts of potassium and low amounts of calcium. Soybean oil contains the highest concentration of sodium, coconut oil contains the highest concentration of calcium while olive oil contains the highest potassium proportion among the studied oils. As for the amino acids content, only coconut oil was found to contain most of the analyzed amino acids on contrast to the other two oils. Arginine was the predominant amino acid in the oils of soybean and coconut $(27.77$ and $26.96 \mathrm{mg} / 100 \mathrm{ml})$ respectively. The nutritional profiles of the oils were presented in Table 2.

Table 2: Nutritional profiles of olive oil, soybean oil and coconut oil

\begin{tabular}{|c|c|c|c|}
\hline Reference & Olive Oil & Soybean Oil & Coconut Oil \\
\hline \multicolumn{4}{|c|}{ Vitamin content $(\mu \mathrm{g} / 100 \mathrm{ml})$} \\
\hline Niacin (B3) & 4.45 & Traces & Traces \\
\hline Pyridoxine (B6) & 3.358 & 1.282 & Traces \\
\hline Cobalamin (B12) & 3.316 & 3.627 & 5.710 \\
\hline Ascorbic acid & ND & 4.244 & 3.706 \\
\hline$\beta$-Carotene (A) & 86.92 & 109.80 & 20.63 \\
\hline$\alpha$-Tocopherol (E) & 1.12 & 5.52 & 228.40 \\
\hline \multicolumn{4}{|c|}{ Mineral content $(\mathrm{mg} / 100 \mathrm{ml})$} \\
\hline Sodium & 968.00 & 992.40 & 974.40 \\
\hline Potassium & 52.60 & 48.00 & 41.60 \\
\hline Calcium & 0.64 & 15.40 & 21.80 \\
\hline Magnesium & 18.20 & 18.60 & 21.20 \\
\hline Iron & 8.43 & 2.70 & 8.01 \\
\hline Manganese & 0.02 & 0.05 & 0.01 \\
\hline Zinc & 0.40 & 1.00 & 0.20 \\
\hline \multicolumn{4}{|c|}{ Amino acids content $(\mathrm{mg} / 100 \mathrm{ml})$} \\
\hline Aspartic acid & ND & ND & 0.46 \\
\hline Theronine & ND & ND & 0.68 \\
\hline Seronine & ND & ND & 6.07 \\
\hline
\end{tabular}




\begin{tabular}{|l|l|l|l|}
\hline Glutamic acid & ND & 2.57 & 4.48 \\
\hline Proline & ND & ND & ND \\
\hline Glycine & ND & ND & ND \\
\hline Alanine & 0.95 & ND & 0.09 \\
\hline Valine & ND & ND & 0.05 \\
\hline Methionine & ND & ND & ND \\
\hline Isoleucine & ND & ND & ND \\
\hline Leucine & ND & ND & 0.28 \\
\hline Tyrosine & ND & ND & ND \\
\hline Phenylalanine & ND & ND & 0.22 \\
\hline Histadine & ND & ND & 0.17 \\
\hline Lysine & 5.14 & 2.95 & 4.37 \\
\hline Arginine & ND & 27.77 & 26.96 \\
\hline
\end{tabular}

ND: not detected

\section{Lipid profiles of the oils}

Following the saponification of the studied oils according to the British Pharmacopeia 2016. The unsaponifiable fractions were separated and analyzed using GC. While the saponifiable fractions, were separately used to prepare the fatty acid methyl esters of the corresponding oils adopting the method described by Ichihara and Fukubayashi (2010) and then analyzed by GC. As shown in table (3), twenty standard hydrocarbons (C11-C30) were assessed in each oil, along with five sterols namely, cholesterol, campasterol, stigmasterol, $\beta$-sitosterol and $\alpha$-amyrine. C27 n-Heptacosane was the most abundant hydrocarbon in all three oils. Cholesterol and $\beta$-sitosterol were not detected in coconut oil, while, campesterol and stigmasterol were detected in all studied oils.

Table 3: Results of GLC analysis of the identified unsaponifiable matter of olive oil, soybean oil and coconut oil

\begin{tabular}{|l|l|l|l|}
\hline \multirow{2}{*}{ Reference } & \multicolumn{4}{l}{ Relative percentage } & Coconut oil \\
\cline { 2 - 4 } & Olive oil & Soybean oil & ND \\
\hline C11 n-Undecane & 1.0563 & 1.2675 & ND \\
\hline C12 n-Dodecane & 0.0116 & 0.0627 & ND \\
\hline C13 n-Tridecane & 0.4283 & 0.9834 & 0.0911 \\
\hline C14 n-Tetradecane & 0.3239 & 0.863 & 0.2758 \\
\hline C15 n-Pentadecane & 0.0829 & 2.9711 & 0.7656 \\
\hline C16 n-Hexadecane & 1.1353 & ND & 2.5571 \\
\hline C17 n-Heptadecane & 1.1341 & 0.2431 & 2.9365 \\
\hline C18 n-Octadecane & 1.1398 & 5.9754 & 3.7815 \\
\hline C19 n-Nonadecane & 4.6776 & 17.2111 & 5.3902 \\
\hline C20 n-Icosane & 0.625 & 0.1543 & 7.3084 \\
\hline C21 n-Henicosane & 15.7537 & 16.4123 & 7.8579 \\
\hline C22 n-Docosane & 6.9490 & ND & 9.0166 \\
\hline C23 n-Tricosane & ND & ND & 7.8800 \\
\hline C24 n-Tetracosane & ND & 0.9615 & 3.2816 \\
\hline C25 n-Pentacosane & 1.1349 & 3.3761 & \\
\hline
\end{tabular}




\begin{tabular}{|l|l|l|l|}
\hline C26 n-Hexacosane & 1.388 & 14.9123 & 3.051 \\
\hline C27 n-Heptacosane & 35.8514 & 18.3413 & 11.9952 \\
\hline C28 n-Octacosane & 4.5681 & 0.3912 & 8.5935 \\
\hline C29 n-Nonacosane & 5.1979 & ND & 4.4054 \\
\hline C30 n-Triacotane & 3.747 & 6.7214 & 17.105 \\
\hline Cholesterol & 3.1967 & 3.8923 & ND \\
\hline Campesterol & 2.1837 & 2.2746 & 2.4451 \\
\hline Stigmasterol & 2.8044 & 0.9882 & 0.4488 \\
\hline $\boldsymbol{\beta}-$ Sitosterol & 3.4595 & 1.7364 & ND \\
\hline $\boldsymbol{\alpha}-$ Amyrine & 2.7817 & ND & 0.4994 \\
\hline
\end{tabular}

According to the results shown in table (4), the unsaturated fatty acids predominates the fatty acid fractions of olive and soybean oils with relative percentages of $(84.16 \%$ and $62.74 \%)$ respectively. On the other hand, the saturated fatty acids represented the majority of fatty acids of coconut oil $(95.19 \%)$. Olive oil contains the highest percentage of mono-unsaturated fatty acid (MUFA) as oleic acid (30.23\%) and poly-unsaturated fatty acids (PUFA); linoleic acid (7.74\%), linolenic acid (1.27\%) and arachidonic acid (42.95\%). Soybean follows olive oil in this percentage as it mainly contains linoleic acid (33.03\%) followed by oleic acid and linolenic acid.

Table 4: Results of GLC analysis of the identified fatty acids of olive oil, soybean oil and coconut oil

\begin{tabular}{|c|c|c|c|}
\hline \multirow[t]{2}{*}{ Reference } & \multicolumn{3}{|c|}{ Relative percentage } \\
\hline & Olive oil & Soybean oil & Coconut oil \\
\hline Caprylic acid C8 (0) & ND & 3.47744 & 7.49276 \\
\hline Capric acid C10 (0) & 2.23489 & ND & 5.87549 \\
\hline Lauric acid C12 (0) & 1.96350 & 1.92572 & 52.53590 \\
\hline Tridecanoic C13 (0) & 1.82106 & ND & ND \\
\hline Myristic acid C14 (0) & 3.97467 & ND & 19.79576 \\
\hline Palmitic acid C16 (0) & 3.23581 & 4.72993 & 7.09982 \\
\hline Stearic acid C18 (0) & 2.23573 & 14.97243 & 2.25345 \\
\hline Behenic acid C22 (0) & ND & 12.14963 & ND \\
\hline Oleic acid C18 (1) $\omega 9$ & 30.23044 & 21.20814 & 4.23181 \\
\hline Linoleic acid C18(2) $\omega 6$ & 7.73774 & 33.03382 & 0.57229 \\
\hline Linolenic acid C18(3) $\omega 3$ & 1.26674 & 8.50289 & ND \\
\hline Arachidonic acid C20(4) $\omega 6$ & 42.94693 & ND & ND \\
\hline Percentage of unsaturated fatty acids & 84.16 & 62.74 & 4.81 \\
\hline Percentage of saturated fatty acids & 15.84 & 37.26 & 95.19 \\
\hline
\end{tabular}

ND: not detected

\section{Effect of olive oil, soybean oil and coconut oil supplemented feed on serum lipid profiles}

As shown in table 5 and figure 1, the mean serum level of total cholesterol was significantly increased in three different oil groups compared to the control group, $\mathrm{P}$ value was $<0.001$. The mean serum level of HDL- 
cholesterol was significantly raised in olive oil group compared to control group and the other two oils groups $(P$ value $<0.001)$.

On the other hand, the mean serum level of LDL-cholesterol and TG were significantly reduced in the olive oil group compared to control group and the other two oils groups $(P$ value $<0.001)$.

Table 5: Effect of olive oil, soybean oil and coconut oil supplemented feed on serum lipid profiles

\begin{tabular}{|l|l|l|l|l|}
\hline Groups & \multicolumn{1}{|c|}{$\begin{array}{c}\text { Total cholesterol } \\
(\mathbf{m g} / \mathbf{d L})\end{array}$} & $\begin{array}{c}\text { HDL-C } \\
(\mathbf{m g} / \mathbf{d L})\end{array}$ & $\begin{array}{c}\text { LDL-C } \\
(\mathbf{m g} / \mathbf{d L})\end{array}$ & \multicolumn{1}{|c|}{ TG (mg/dL) } \\
\hline Control & $58.2 \pm 4.49$ & $34 \pm 0.89$ & $32.3 \pm 1.37$ & $47.3 \pm 3.26$ \\
\hline Olive oil & $66.8 \pm 4.71^{a}$ & $35.8 \pm 0.75^{a}$ & $24.5 \pm 1.05^{a}$ & $59 \pm 2.82^{a}$ \\
\hline Soybean oil & $69.2 \pm 3.13^{a}$ & $34.2 \pm 0.75^{b}$ & $28.3 \pm 0.81^{a b}$ & $79.3 \pm 6.12^{a b}$ \\
\hline Coconut oil & $66.8 \pm 3.54^{a}$ & $32.7 \pm 1.51^{b}$ & $28.3 \pm 0.81^{a b}$ & $73.1 \pm 5.26^{a b}$ \\
\hline
\end{tabular}

Results were expressed as mean \pm SD and analyzed using one-way ANOVA followed by Bonferroni's post hoc test, ${ }^{a}$ significant from control at $P<0.001,{ }^{b}$ significant from olive oil group at $P<0.001$.

Effect of different oils supplemented diet on serul lipid profile

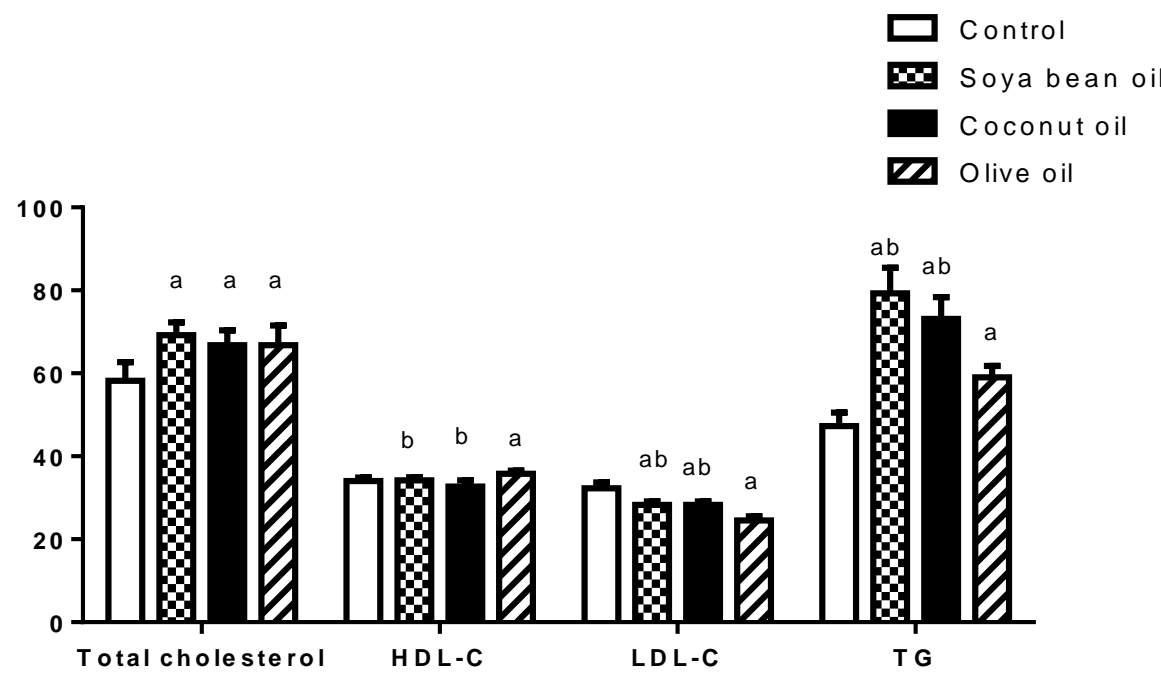

Fig 1. Effect of olive oil, soybean oil and coconut oil supplemented feed on serum lipid profiles

Results were expressed as mean \pm SD and analyzed using one-way ANOVA followed by Bonferroni's post hoc test, a: significant from control at $P<0.001$, b: significant from olive oil group at $P<0.001$. 


\section{Effect of olive oil, soybean oil and coconut oil supplemented feed on serum} FFA levels

The mean serum level of FFA was significantly increased in three different oil groups compared to the control group, $\mathrm{P}$ value was $<0.001$.

On the other hand, the mean serum level of FFA was significantly reduced in the olive oil group compared to the other two oils groups ( $P$ value $<0.001)$. The results were presented in Table 6 and figure 2 .

Table 6: Effect of olive oil, soybean oil and coconut oil supplemented feed on serum free fatty acids levels

\begin{tabular}{|l|l|}
\hline Groups & Free fatty acid (mg/dL) \\
\hline Control & $14.9 \pm 0.96$ \\
\hline Olive oil & $18.02 \pm 0.99^{a}$ \\
\hline Soybean oil & $21.9 \pm 1.16^{a b}$ \\
\hline Coconut oil & $31.7 \pm 2.02^{a b}$ \\
\hline
\end{tabular}

Results were expressed as mean $\pm \mathrm{SD}$ and analyzed using one-way ANOVA followed by Bonferroni's post hoc test, ${ }^{a}$ significant from control at $P<0.001,{ }^{b}$ significant from olive oil group at $P<0.001$.

The effect of different oils on serum free fatty acids level

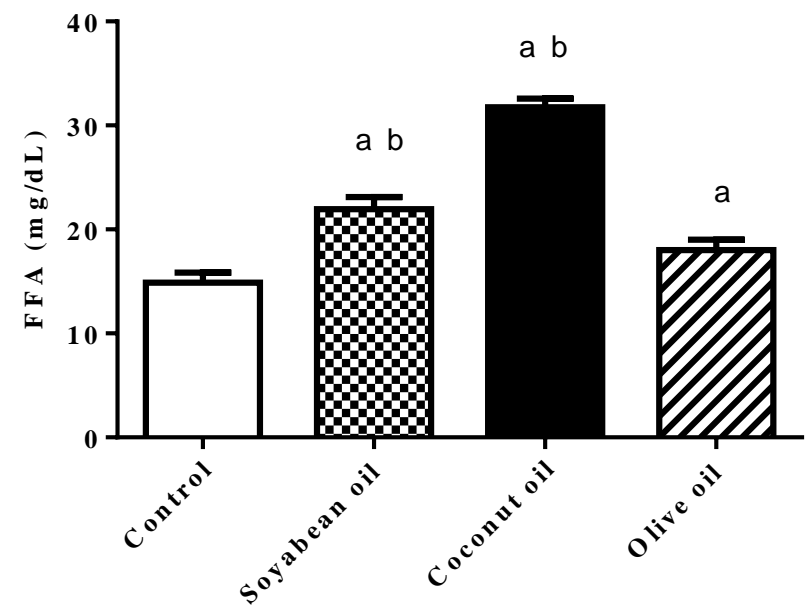

Fig 2. Effect of olive oil, soybean oil and coconut oil supplemented feed on serum free fatty acids levels

Results were expressed as mean $\pm \mathrm{SD}$ and analyzed usingone-way ANOVA followed by Bonferroni's post hoc test, a: significant from control at $P<0.001$, b: significant from olive oil group at $P<0.001$. 


\section{Effect of olive oil, soybean oil and coconut oil supplemented feed on body weight in rats}

The $\% \Delta$ weight was significantly increased in coconut oil group compared to the control group, $\mathrm{P}$ value was $<0.01$. The $\% \Delta$ weight was significantly reduced in olive oil group compared to control, soybean oil and coconut oil groups $(\mathrm{P}$ value $<0.001)$. The results were presented in Table 7 and figure 3 .

Table 7: Effect of olive oil, soybean oil and coconut oil supplemented feed on body weight in rats

\begin{tabular}{|l|l|l|l|}
\hline Groups & Initial weight $(\mathbf{g m})$ & Final weight $\mathbf{( g m})$ & $\mathbf{\%} \mathbf{\Delta}$ weight $(\mathbf{g m})$ \\
\hline Control & $152 \pm 11.02$ & $178 \pm 10.3$ & $16.9 \pm 3.44$ \\
\hline Olive oil & $153 \pm 5.82$ & $171 \pm 16.8$ & $12.4 \pm 3.2^{a}$ \\
\hline Soybean oil & $155 \pm 13.5$ & $188 \pm 20.52$ & $20.7 \pm 5.42^{b}$ \\
\hline Coconut oil & $145 \pm 11.3$ & $181 \pm 20.66$ & $24.8 \pm 8.25^{a b}$ \\
\hline
\end{tabular}

Results were expressed as mean \pm SD and analyzed using one-way ANOVA followed by Bonferroni's post hoc test, ${ }^{a}$ significant from control at $P<0.01,{ }^{b}$ significant from olive oil group at $P<0.001$.

The effect of different oils on body weights in rats

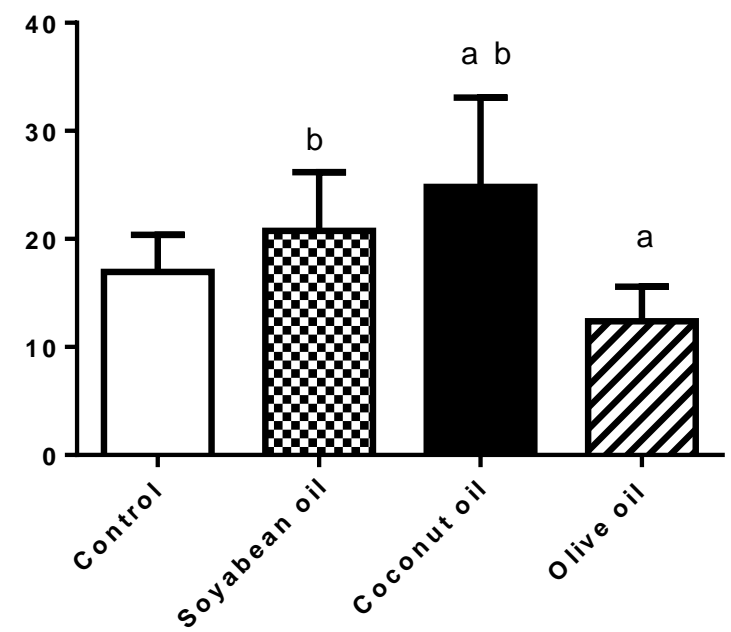

Fig 3. Effect of olive oil, soybean oil and coconut oil supplemented feed on body weight in rats

\section{Discussion}

The results of the current study that tested the consumption of olive oil, soybean oil and coconut oil confirmed the variability of the chemical composition of the three oils which was further reflected on the lipid profiles, free fatty acids serum levels and body weights of the experimental rats. 
Our results showed that serum analysis of olive oil supplemented-feed rats had the highest HDL levels, significantly different from the control group. Similarly, previous studies related the elevation of HDL levels to the increased MUFA intake (as oleic acid in olive oil) (Aguilera et al. 2005). The present study supports this hypothesis as olive oil (rich in MUFA) showed better results than the other two oils. In addition, olive oil had a lowering effect on LDL levels; this finding was in accordance with (Lastra et al. 2001), this may be also attributed to its content of MUFA. (Kien et al. 2013). Basically, unsaturated fatty acids lower serum LDL by different mechanisms including redistribution of cholesterol between plasma and tissue pools (Matson and Grundy 1985), up-regulation of the LDL receptor (Fernandez and McNamara 1989) or increasing LDL apoB-100 fractional catabolism (Turner et al. 1981).

Accordingly, it can be concluded that, the positive effect of olive oil on lipid profile is due to the predomination of UFA $(84.16 \%)$ over the SFA fractions. This attribution is supported by the results of several studies (German and Dillard 2004; Lefevre et al. 2005; Fernandez and West 2005 and World Health Organization 2008). Moreover, olive oil was found to have the least elevating effect on TGs among the other oils. Previous studies had shown that the positive effect of olive oil on lipid profile is not only restricted to MUFA and PUFA percentages; but also to the synergistic role of minor constituents (Al Juhaimi et al. 2017). Therefore, in this study, we examined the vitamins, minerals and amino acids contents of the three oils.

Coconut oil, rich in SFA, showed a similar effect to that of olive oil on the serum cholesterol levels,

This can be justified by the assumption of the biochemical link between the tocopherol levels (found in a significantly higher proportion in coconut oil $228.40 \mu \mathrm{g} / 100 \mathrm{ml}$ than olive oil $1.12 \mu \mathrm{g} / 100 \mathrm{ml}$ ) and the degree of unsaturation in vegetable oils (Kamal Eldin and Anderson 1997). Another justification to this result, may be related to its high content of Medium Chain Fatty Acids (MCFA) (approximately 66\%); MCFA are absorbed and transported through the portal vein to the liver where they are rapidly oxidized, generating energy (Schumacher et al. 2016). According to (Liu et al. 2017), MCFA reduce serum cholesterol by regulating the metabolism of bile acid.

Our study proved that coconut oil has the least favorable effect on HDL; this finding is in agreement with (Paz et al. 2010). However, (Feranil et al. 2011) reported positive association between coconut oil intake and the HDL levels.

Soybean oil showed a decreased LDL and an increased triglycerides serum levels more than the control group but less than olive oil fed group. The content of PUFA (linoleic acid 33.03\%) in soybean may be the reason for this, as there is a relationship between PUFA and increasing the sensitivity and number of LDL receptors (Mustad et al. 1996). However, the difference 
between the effects of the olive and soybean oils can be attributed to the presence of a relatively lower total unsaturation percentage in soybean oil than olive oil. Our results revealed that the serum levels of free fatty acids were significantly reduced in the olive oil group compared to the other two oils supplemented-feed groups. Where free fatty acids are intermediary metabolites that are formed from the hydrolysis of triglycerides by lipoprotein lipase and hormone-sensitive lipase, so that could explain its effect on reducing the TG in blood as well.

Also, this research verified that olive oil supplemented diet was superior in its effect on the rats' body weight where the difference in the body weights before and after dieting on olive oil was $(12.4 \pm 3.2)$ that was even lower than that of the control group $(16.9 \pm 3.44)$ and much lower than the other two oils supplemented groups.

\section{Conclusion}

The results reported herein confirmed that unsaturated fatty acids are primarily recommended for daily intake. Olive oil, the richest studied oil in UFA, showed favorable effect on lipid profiles, therefore, it is regarded as a strong evidence for assuming this recommendation. Olive oil has the least elevating effect on total cholesterol among the other oils. Olive oil significantly decreases LDL cholesterol, and triglycerides. On the other hand, olive oil significantly elevates HDL which is the good cholesterol exerting the cardio-protective effects. Olive oil supplemented diet significantly reduced the serum levels of free fatty acids and did not increase the rats body weight. Hence, olive oil supplemented diets could be of clinical benefit to individuals at risk of cardiovascular disease.

\section{Conflict of interests}

The authors declare no conflicts of interest associated with this publication.

\section{References:}

1. Aguilera, M. P., Beltránm G., Ortega, D., Fernández, A., Jiménez, A., Uceda, M. (2005) Characterisation of virgin olive oil of Italian olive cultivars: 'Frantoio' and 'Leccino', grown in Andalusia. Food Chemistry, 89(3):387-391

2. Al Juhaimi, F., Ozcan, M. M., Ghafoor, K., Oladipupo, Q. A., Babiker, E. E. (2017) Phenolic Compounds and Sterol Contents of Olive (Olea Europaea L.) Oils Obtained From Different Varieties., 49(1), 169172. 
3. Alonso, A., Martínez-González, M. A. (2004) Olive oil consumption and reduced incidence of hypertension: The SUN study. Lipids., 39:1233-1238.

4. A.O.A.C. (1995) 16th ed. Washington DC. Official Methods of Analysis of the Association of Official Analytical Chemist. Rockville, MD, USA: AOAC International.

5. Batifoulier, F., Verny, M. A., Besson, C., Demigne, C., Remesy, C. (2005) Determination of thiamine and its phosphate esters in rat tissues analyzed as thiochromes on a RP-amide C16 column. J Chromatogr B Analyt Technol Biomed Life Sci., 816:67-72.

6. Beyer, R. S., Jesnsen, L. S. (1989) Overestimation of the cholesterol content of eggs. J Agric Food Chem., 37:917-20.

7. British Pharmacopoeia (2016), TSO, ISBN: 0113230087

8. Cosmos, E. and Simon-Sarkadi, L. (2002) Characterization of tokaj wines based on free amino acid and biogenic amine using ionexchange chromatography. Chromatographia Supplement, 56:185-188

9. Estruch, R., Martínez-González, M. A., Corella, D., Salas-Salvadó, J., Ruiz-Gutiérrez, V., Covas, M. I., Fiol, M., Gómez-Gracia, E., LópezSabater, M.C., Vinyoles, E., Arós, F., Conde, M., Lahoz, C., Lapetra, J., Sáez, G., Ros, E. (2006) Effects of a Mediterranean-style diet on cardiovascular risk factors: A randomized trial. Ann Intern Med., 145:1-11.

10. Esrey, K. L., Joseph, L., Grover, S. A. (1996) Relationship between dietary intake and coronary heart disease mortality: lipid research clinics prevalence follow-up study. J Clin Epidemiol., 49:211-6

11. Evangelisti, F., Zunin, P., Tisconia, E., Petacchi, R., Drava, G., Lanteri, S. (1997) Stability to oxidation of virgin olive oils as related to olive conditions: Study of polar compounds by chemometric methods. J Am Oil Chem Soc., 74:1017-22.

12. Feranil, A. B. Duazo, P. L. Kuzawa, C. W., Adair, L. S. (2011). Coconut oil predicts a beneficial lipid profile in pre-menopausal women in the Philippines. Philippine Political Science Journal, 20(2):190-195.

13. Fernandez, M. L., McNamar, D. J. (1989) Dietary fat-mediated changes in hepatic apoprotein $\mathrm{B} / \mathrm{E}$ receptor in the guinea pig: effect of polyunsaturated, monounsaturated, and saturated fat. Metabolism, 38(11):1094-102.

14. Fernandez, M. L. and West, K. L. (2005) Recent Advances in Nutritional Sciences Mechanisms by which Dietary Fatty Acids Modulate Plasma Lipids. Society, 18:15-17.

15. German, J. B. and Dillard, C. J. (2004) Saturated fats: what dietary intake? Am J Clin Nutr, 80:550 -9. 
16. Howard, B. V., Van Horn, L., Hsia, J., Manson, J. E., Stefanick, M. L., Wassertheil-Smoller, S., Kuller, L. H., LaCroix, A. Z., Langer, R. D., Lasser, N. L., Lewis, C. E., Limacher, M. C., Margolis, K. L., Mysiw, W. J., Ockene, J. K., Parker, L. M., Perri, M. G., Phillips, L., Prentice, R. L., Robbins, J., Rossouw, J. E., Sarto, G. E., Schatz, I. J., Snetselaar, L. G., Stevens, V. J., Tinker, L. F., Trevisan, M., Vitolins, M. Z., Anderson, G. L., Assaf, A. R., Bassford, T., Beresford, S. A., Black, H. R., Brunner, R. L., Brzyski, R. G., Caan, B., Chlebowski, R. T., Gass, M., Granek, I., Greenland, P., Hays, J., Heber, D., Heiss, G., Hendrix, S. L., Hubbell, F. A., Johnson, K. C., Kotchen, J. M. (2006) Low-fat dietary pattern and risk of cardiovascular disease: the Women's Health Initiative Randomized Controlled Dietary Modification Trial, JAMA 295:655-66

17. Hu, F. B., Willett, W. C. (2002) Optimal diets for prevention of coronary heart disease, JAMA 288:2569-78

18. Ichihara, K. and Fukubayashi, Y. (2010) Preparation of fatty acid methyl esters for gas-liquid chromatography. J Lipid Res., 51(3): 635640.

19. Kamal-eldin, A. and Andersson, R. (1997) A Multivariate Study of the Correlation Between Tocopherol Content and Fatty Acid Composition in Vegetable Oils. Journal of the American Oil Chemists' Society, 5: 375-380.

20. Kien, C. L. Bunn J. Y., Tompkins, C. L., Dumas, J. A., Crain, K. I., Ebenstein, D. B., Koves, T. R., Muoio, D. M. (2013) Substituting dietary monounsaturated fat for saturated fat is associated with increased daily physical activity and resting energy expenditure and with changes in mood. Am J Clin Nutr., 4:689-97.

21. Kris-Etherton, P. (1999) Monounsaturated fatty acids and risk of cardiovascular disease. Circulation, 100: 1253-1258.

22. Lastra, C. A., Barranco, M. D., Motilva, V., Herrerías, J. M. (2001) Mediterranean diet and health: biological importance of olive oil. Curr Pharm Des., 7(10):933-50.

23. Lefevre, M., Lovejoy, J. C., Smith, S. R., Delany, J. P., Champagne, C., Most, M. M., Denkins, Y., de Jonge, L., Rood, J., Bray, G. A. (2005) Comparison of the acute response to meals enriched with cisor trans-fatty acids on glucose and lipids in overweight individuals with differing FABP2 genotypes. Metabolism, 54(12):1652-8.

24. Lichtenstein, A. H., Appel, L. J., Brands, M., Carnethon, M, Daniels, S., Franch, H. A., Franklin, B., Kris-Etherton, P., Harris, W. S., Howard, B., Karanja, N., Lefevre, M., Rudel, L., Sacks, F., Van Horn, L., Winston, M., Wylie-Rosett, J. American Heart Association Nutrition Committee (2006) Diet and lifestyle recommendations 
revision 2006: a scientific statement from the American Heart Association Nutrition Committee, Circulation 114:82-96

25. Liu, Y., Zhang, Y., Zhang, X., Xu, Q., Yang, X., Xue, C. (2017) Medium-chain fatty acids reduce serum cholesterol by regulating the metabolism of bile acid in C57BL/6J mice. Food Funct., 8(1):291-298.

26. Mattson, F.H. and Grundy, S. M. (1985) Comparison of effects of dietary saturated, monounsaturated, and polyunsaturated fatty acids on plasma lipids and lipoproteins in man. J Lipid Res., 26(2):194-202.

27. Martínez-González, M. A. and Sánchez-Villegas, A. (2004) The emerging role of Mediterranean diets in cardiovascular epidemiology: Monounsaturated fats, olive oil, red wine, or the whole pattern? Eur J Epidemiol., 19:9-13.

28. Mendis, S., Puska, P. and Norrving, B., (2011). Global Atlas on cardiovascular disease Prevention and control. World Health Organization, Geneva, 164.

29. Mustad, V. A., Ellsworth, J. L., Cooper, A. D., Kris-Etherton, P. M. and Etherton, T. D. (1996) Dietary linoleic acid increases and palmitic acid decreases hepatic LDL receptor protein and mRNA abundance in young pigs. The Journal of Lipid Research, 37: 2310-2323.

30. Paz, C., Jimeno, C., Rody S, (2010) The Effect of Virgin Coconut Oil on Lipid Profile and Fasting Blood Sugar: A Phase I Clinical Trial. 48(2):1-6.

31. Pietinen, P., Ascherio, A., Korhonen, P., Hartman, A. M., Willett, W. C., Albanes, D., Virtamo, J. (1997) Intake of fatty acids and risk of coronary heart disease in a cohort of Finnish men. The AlphaTocopherol, Beta-Carotene Cancer Prevention Study. Am J Epidemiol., 145:876-87

32. Prasad, R. et al. (2016) Effect of vegetable oils on the lipid profile and antioxidant status in Wistar rats: A comparative study. 3(2):109-114.

33. Rabrenovic, B., Dimic, E., Maksimovic, M., Sobajic, S. and GajicKrstajic L. (2011) Determination of fatty acid and tocopherol compositions and the oxidative stability of walnut (Juglans regia L.) cultivars grown in Serbia. Czech J. Food Sci., 29: 74-78.

34. Rajaram, S., Burke, K., Connell, B., Myint, T. and Sabaté, J. (2001) A Monounsaturated Fatty Acid-Rich Pecan-Enriched Diet Favorably Alters the Serum Lipid Profile of Healthy Men and Women. J. Nutr., 131: 2275-2279.

35. Romeu-Nadal, M., Morera-Pons, S., Castellote, A.I., Lopez-Sabater, M.C. (2006) Rapid high-performance liquid chromatographic method for Vitamin $\mathrm{C}$ determination in human milk versus an enzymatic method. J Chromatogr B Analyt Technol Biomed Life Sci., 830:41-6. 
36. Schumacher, B. D. O., Preuss, E. M., Vargas, C. G., Helbig, E. (2016) Coconut oil on biochemical and morphological parameters in rats submitted to normolipidic and hyperlipidic diets. Cienc. Rural, 46 (10): 1818-1823.

37. Shepherd, J., Harden, A., Rees, R., Brunton, G., Garcia, J., Oliver, S., Oakley, A. (2006) Young people and healthy eating: a systematic review of research 37 on barriers and facilitators. Health Educ Res. 21(2): 239-257.

38. Siri-Tarino, P. W., Sun, Q. Hu, F. B. and Krauss, R. M. (2010) Saturated fat, carbohydrate, and cardiovascular disease. Am J Clin Nutr., 91(3): 502-509.

39. Vogler, G. A., Suckow, M. A., Weisbroth, S., Franklin, C. L. (2006) Anesthesia and analgesia in the laboratory rat. Elsevier Academic Press, New York, USA, 627-695.

40. Turner, J. D., Le, N. A., Brown, W. V. (1981) Effect of changing dietary fat saturation on low-density lipoprotein metabolism in man. Am J Physiol., 241(1): E57-63.

41. World Health Organization (2008) Fats and fatty acids in human nutrition. Report of an expert consultation., FAO food and nutrition paper. doi: I1953E/1/11.10.

42. World Health Organization (2017) World Heart Day 2017, Scale up prevention of heart attack and stroke, available at www.who.int/global_hearts, retrieved Feb 2018

43. Xu, J., Eilat-Adar, S., Loria, C., Goldbourt, U., Howard, B. V., Fabsitz, R. R., Zephier, E. M., Mattil, C., Lee, E. T. (2006) Dietary fat intake and risk of coronary heart disease: the Strong Heart Study. Am J Clin Nutr., 84:894-902

44. Zimmerman, M. and Snow, B. (2012) Essentials of Nutrition: A Functional Approach. ISBN: 978-1-4533-5246-5 